\title{
UDK $811.16^{\prime} 373$
}

\section{ORIGINAL SCIENTIFIC WORK}

DOI: 10,33669/KJ2020-31-01

primljeno / received: 29. 8. 2020.

prihvaćeno / accepted: 16. II. 2020.

\section{MARC L. GREENBERG}

Department of Slavic and Eurasian

Languages \& Literatures

University of Kansas

1445 Jayhawk Blvd.

Lawrence, KS 66045-7590, USA

mlg@ku.edu

\section{Melioration in South Slavic. The case of Slavic *gyzd-}

Abstract: The article discusses the origin and development of the Proto-Slavic word * $g y z d-\measuredangle /-a$ and its derivatives in the Slavic daughter languages with particular attention to the formal and semantic developments that help to explain why the word went from a negative meaning ('mud, excrement', 'something disgusting') in Northern Slavic (West and East) to a positive meaning ('adornment, embellishment', 'showiness, suavity') in South Slavic.

Keywords: etymology, Proto-Slavic, word-formation, semantic change 


\section{Introduction}

This paper focus on the semantic development of PSl. ${ }^{*} g y z d-\tau /-a$ and its derivatives in South Slavic, where the word has shifted in meaning from negative to positive. ${ }^{1}$ Details are added to the reconstruction to provide a richer account of the semantic development. The etymology of the word is still open to some interpretation for at least the following reasons: (1) The full development of the word in Slavic has not yet been adequately explained, (2) the semantics of the word in West vs. South Slavic are strikingly opposite, raising questions of how the semantic reevaluation occurred, and (3) in relation to the previous notion, the distribution of the word is indicative of lexical relationships of Slavic dialects dating to the time of the disintegration of Common Slavic and presumed migrations (ca. 500 AD) and as such sheds light on the dialect structure of Late Common Slavic at the time of expansion.

The ESSJa (Trubačev 1980 s.vv.) lists the following reconstructed forms assigned to Common Slavic that are pertinent to the word in question (followed by an overview of attestations):

${ }^{*}$ guditi / ${ }^{\star}$ gydati 'to vilify, denigrate', attested in Slovak hudit' 'to abuse, vilify'; Russian dialect gudit' 'to lure, deceive', 'fail to recognize virtue, to criticize', gúdit' 'to blame, condemn', 'seduce, deceive'; Ukrainian húdyty 'vilify, condemn'; Belarusian gudzic' to judge, condemn'; ' gudati Czech houdati 'to engage in debauchery', Upper Sorbian hudać 'to tell fortunes'.

This paper was written during the COVID-19 pandemic, during which physical access to libraries was significantly reduced or impossible. In the course of gathering data I was able to compensate for the lack of access to sources by the good will of fine colleagues, including Siniša Habijanec (Bratislava/Zagreb), Mate Kapović (Zagreb), Corinne Leschber (Berlin), Leendert van der Miesen (Berlin), and Marko Snoj (Ljubljana), who helped me confirm data points or find key sources. I am also indebted to a thoughtful anonymous reviewer, who provided excellent substantive advice. Further, I am more grateful than ever to librarians throughout North America and Europe who had the foresight even before the pandemic to make available an ever-growing number references in free open-access formats through their institutional repositories. 
*gyditi Slovak hydit' 'to make ugly, distort'; Lower Sorbian hyźiś 'to hate'; Russian dialect gídit' 'to elicit disgust, make nauseated'; Ukrainian hydýty 'to muddy, soil', 'make unclean' and hýdyty 'to disdain, to feel disgust'; Belarusian dialect hydýty 'to muddy, soil', 'to berate, condemn'; Polish hydzić 'to make something unpleasant' is presumed to have been borrowed from Ukrainian.

${ }^{*} \boldsymbol{g} \boldsymbol{y d \boldsymbol { b }} /{ }^{*} \boldsymbol{g} \boldsymbol{y d a}$ Czech hyd 'monster', 'disgust', 'insects', 'domestic bird'; Czech dialect 'insects, parasites'; Slovak (collective masc. sg.) 'domestic bird', 'vermin'; Upper Sorbian hida (fem. sg.) 'hatred'; Old Polish gid 'disgust'; Russian dialect gid 'slithering creature'; Ukrainian hid 'something disgusting'; Belarusian dialect hidá 'something disgusting'.

* gyzdati 'to decorate, dress up' (transitive; with se 'to dress oneself up'), attested in BCMS, Slovene.

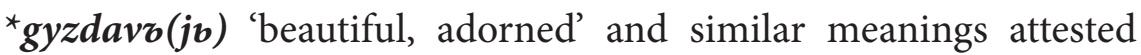
in Bulgarian, Macedonian, BCMS, Slovene; but Polish dialect gizdawy 'one who urinates in one's bed', 'messy, unkempt person', 'shameless person'.

${ }^{*} \boldsymbol{g} \boldsymbol{y z d i t i}$ - the same meaning as ${ }^{*}$ gyzdati is attested in Bulgarian, Macedonian, BCMS, Slovene; though gyzno 'to get something wet or muddy' is attested in a Bulgarian dialect; in Czech hyzditi 'to disfigure,' 'to scold' and Polish dialect giździć 'to get dirty, muddy', 'to shame'.

${ }^{\star} \boldsymbol{g} y \boldsymbol{z d \boldsymbol { b }} /{ }^{*}(\boldsymbol{o}) \boldsymbol{g} \boldsymbol{y} \boldsymbol{z d \boldsymbol { d }} \boldsymbol{-}$ - 'decoration, finery' attested in BCMS; in Old Czech and Czech dialects hyzd 'something disgusting' and in Polish dialects meanings such as 'wretch', 'abomination', 'filth', 'mess'. An $a$-stem variant ${ }^{*} g y z d a$ of the latter form almost certainly should be reconstructed, cf. Czech ohyzda 'something disgusting', BCMS gizda 'adornment, elegance', Slovene gízda/gîzda 'luxury, splendor'.

The roots ${ }^{\star} g y d$ - and ${ }^{\star} g y z d$ - proliferated in further word formational process, most richly in South Slavic, to a lesser extent in West Slavic. Examples: 


\section{KNJIŽEVNI JEZIK 31, 2020. [9-23]}

\section{West Slavic}

Polish ohyda, ohida and ochida attested in the 16th c. 'something that elicits a feeling of disgust, revusion'; ohyzda 'disgrace, shame'; gizd, gizda 'dirt, mud'; derivations: ohydny, ohydzić, zohydzić 'to disgust'; the forms with $-h$ - are presumed to be Czech intrusions (SEJP s.v. ohyda); Slovak (1750) hyzdny' 'ugly, bad, hideous' (HHSJ s.v.); it shows up also in a jocular nickname, Hýžd' 'butthead' (Skulina 1964: 175); Old Czech (ESSČ s.vv.) hýždě, hýžě 'buttocks' < gyzd-j-a (MSS s.v.).

\section{South Slavic}

Slovene gízdav/gizdäv, gizdáva 'showy, ostentatious' (antiquated); gízdavost/gizdávost 'showiness, ostentation' (antiquated) (SSKJ s.vv.)

BCMS gízdalac, gízdaoca 'a person who dresses up', gizdānje 'the act of dressing up', gizdaviti se (attested only once in the 16th c.), gizdavljahan, gizdavljahna (attested only in Stulli's dictionary), gizdavōst 'state, characteristic of being dressy', gizdèlin 'a dandy', gizdeliniti se and gizdeliti se 'to behave like a dandy', gizdèlinski 'pertaining to a dandy', gizdèlinstvo 'dandification', gizdòca (attested twice in the 17-18th cc.), gizdovjùbiv 'characterized by inclination to dandify', gizdòljüblje 'characteristic of being inclined to dandify', gïzdōst 'quality of being dressy', gizdovati (attested once in the 16th c.), as well as diminutives in -ulić, -ulj, -uša (RHSJ s.vv.);

Macedonian gizdav, gizdavec, gizdavina, gizdavica, gizdavost, gizdalka (= gizdavica), gizdalo 'instrument by which one dresses up', 'dandy', gizdenje (deverbal from gizdi), gizdi 'dresses up' (RMJ s.vv.);

Bulgarian gízdjă (colloquial) 'to dress up', gízdav, -a, -o (colloquial) 'a person, usually a woman, with a beautiful exterior or prettily dressed' and (dialectal) 'a person with a positive or favorable character', gizdavost 'the quality of being dressy' ( $R B E$ s.vv.). Only Gerov's dictionary (1895: s.v.) lists the verb gizna 'to stand or walk in water or mud' with the archaic meaning found in the northern Slavic languages. 


\section{Linguistic geography}

Of some interest here is the fact that the semantic innovation occurs not only within South Slavic, but that it is also all-South-Slavic with relative uniformity from west to east and showing a sharp contrast with North Slavic altogether. If the semantic change were to have taken place prior the assimilation of the Pannonian Slavs to Hungarian, then we might expect that some traces of the innovation would be found in West Slavic, for example, in Central Slovak. This may be the case, but so far no evidence in the lexicographical references hint that this is the case.

There is one piece of evidence that the archaism had survived in South Slavic, but it is only a minor trace and it is limited to the evidence in Gerov's Bulgarian dictionary, where the verb gizna, -eš (IMPF.), nagízvam (PF.) (Leskien Class II, -no/e-suffixed verbs), mentioned above, retains the connection with 'disgusting matter'. It should be no surprise that this is the one place where the archaism is found, given that within the -no/e-verbs, following Dickey's observation, the least innovative region with regard to aspectual semantic change in a pan-Slavic perspective lies in the Eastern and Eastern South Slavic areas (Dickey 2001). This accords with Maslov's insight, elaborated further by Sokolov, that the imperfective -no/e-verbs, by virtue of their suffixation, correlate with stable meanings in the verbal roots that combine with them (Sokolov 1978: 8-9). To judge by the absence of a ${ }^{*} g y z(d) n \varrho t i$ entry in the Trubačev etymological dictionary, it is reasonable to surmise that the Bulgarian datum in Gerov's dictionary is isolated, if not unique, within Slavic, though I would expect (in a non-pandemic era) to find attestations in dialect dictionaries at least for Bulgarian data. Georgiev asserts that the verb is isolated in Bulgarian with respect to the rest of Slavic (1958: 13). Nevertheless, this archaism demonstrates that in South Slavic the older meaning was available for building this verb. 


\section{Previous etymologies}

Skok (1971 s.v. gäd < PIE $\left.{ }^{*} g w o \bar{d} h-\right)$ treats both ${ }^{*} g y d z$ and ${ }^{*} g y z d z$, both 'nausea' as derivatives from the same ablauting root, noting the bifurcation between the former, which is not attested in South Slavic, and the latter, which occurs in West Slavic only with negative meanings, while in South Slavic it has developed positive meaning as well as further derivations. He further points out its borrowing in Moldavian Romanian ghizdav, also with positive meaning 'splendid, attractive' as well as ghizd 'Brunnenkranz' and the plant name ghizdeu 'medicago sativa, alfalfa, which implies the melioration development in South Slavic. Further, he explains the $-z d$ - as a result of dissimilation after suffixation in $-d a$ (analogous to pravda, krivda), noting also the parallel in Russian gvazda 'slush' (from the same vrddhi-grade ${ }^{*} g w o \bar{d} d h$-). Baltic forms Lith. geda 'shame', Old Prussian gidan 'shame-ACC.sG.' demonstrate the same negative semantic field, albeit with lengthened $e$-grade. Gluhak (1993: s.v. gizda) generally follows Skok's reconstruction, adding that the $-z d$ - goes back to a doubled - $d d$ - owing to "expressivity," which comports with the general assumption that $-d$ - and $-z d$ - suffixes (albeit on the basis of circular reasoning) are derived from one another (see, for example, Sławski 1974, vol. 1: 63).

Though Bezlaj (1977) does not deal with Slovene gizda directly, he points out two important connections. First, s.v. $g \hat{r} d$ he points out the bifurcation in meanings between South Slavic 'ugly' and North Slavic 'proud, haughty', which he asks the reader (blithely) to compare to gizda. Presumably the matter in question is the bifurcation, though the positive-negative values are reversed geographically. S.v. gvazdati, gvazdam (imperfective) 'to prattle on, to brag' he notes the common PIE source, following Skok, in ${ }^{*} g w o \bar{d} d h$ - relating the verb potentially to govno 'excrement', gizda, gad 'viper', ogaben 'disgusting', though suggests that, alternatively, that the verb in question may merely be an expressive form of other words for talking (gobezdati, gofljati, gobcati).

In ESSJa (1980) the nest of words (s.v. ${ }^{*}$ gyzdati) is associated with the large family of words including the roots ${ }^{*}$ gad-, ${ }^{*}$ gyd-, ${ }^{*}$ gvazd-, in accord with Skok and Bezlaj. 
Snoj (2020) s.v. gizda 'elegance, pride', explains that the differences in meaning point to a Common Slavic starting point in ${ }^{*} g \hat{y} z d z$ 'mud', ${ }^{\star}$ gyzdïti (sę), ${ }^{*}$ gyzdäti (sę) 'to smear with mud', which in turn became generalized in part of the Slavic-speaking territory as 'to make dirty, to ruin', and elsewhere as 'to put on makeup'. Snoj, too, derives the word from ${ }^{*}$ guu $\mathrm{H}$-, ${ }^{\star}$ guou $\mathrm{H}$ - 'mud, excrement'. Snoj thus also updates Pokorny's root reconstruction with regard to the rootfinal laryngeal (Pokorny 1959, entry 735).

Pokorny in turn lists ${ }^{*} g w o \bar{u}$-, ${ }^{\star} g w \bar{u}$ - 'dung, excrement; that which is elicits disgust' with the notation that both Germanic and BaltoSlavic extend the meaning also to small, disgusting animals, crawling animals as well as from meanings referring to 'uncleanliness' to 'disgrace, abhorrence', notably with the extension -dh-: ${ }^{*} g^{w} \bar{e}[u]$ $d h-,{ }^{*} g^{w} \bar{o}[u] d h-,{ }^{*} g^{w} \bar{u} d h$. The unextended root ${ }^{*} g w o u(H)$ - gave rise to the Slavic word ${ }^{*}$ govbno 'excrement' and the lengthened $o$-grade $\left({ }^{*} g w o \bar{u} u(H)-\right)$ to the verb ${ }^{*}$ gaviti 'to cause disgust' (cf. Sn gabiti se 'to be disgusted', OCr gaviti se 'idem', OCz haviti 'to distort, ruin') and in turn a new collective noun * gavěds (cf. Sk háved' 'the unwashed, a mob', Králik 2015: s.v.; Snoj 2020: s.v. gabiti se 'to become nauseated'). The root is extended in Slavic by ${ }^{*}-d-a\left(<\mathrm{PIE}^{*}-d h-e \mathrm{H}_{2}\right)$. Derivatives from other PIE grades also have a - $d h$ - extension, e.g., PIE ${ }^{*}$ gewdh-/gwedh- and ${ }^{*}$ gwōdh- > PSl. ${ }^{*}$ gadt 'snake, viper', cf. Dutch kwaad 'evil, disgusting', MHG quāt 'bad, awful' (cf. German Quatsch 'crap, garbage'), so the Slavic forms in - $d$ - is clearly old (see Skok 1971 s.v. gäd).

To sum things up so far, there is general agreement about the PIE origin of the root, the ablaut relations of the root in PIE and several of the daughter languages, including Slavic, and the broad outlines of the semantic bifurcation within Slavic. An open question is how the Slavic semantic bifurcation proceeded, which, in turn, opens the derivational morphology of ${ }^{\star} g y z d \tau / a$ to further examination.

The West Slavic and East Slavic evidence points to Proto-Slavic ${ }^{\star} g y d-$-, which, it might be noted, Vaillant saw as isolated and unexplained unless it was to be seen as related to ${ }^{*}$ gad (Vaillant 1974: 171). If it 
is decoupled from ${ }^{\star}$ gad-, in contrast to the etymologies proposed above, the $-d$ extension can be motivated with regard to parallels with other Slavic words adjectival formations in Slavic and Baltic, e.g., PSI ${ }^{\star}$ bridokz 'sharp, acute (as with a disease)', cf. Sn bridek 'bitter', BCMS bridak 'sharp', $\mathrm{Cz}$ britký 'sharp, trenchant' (< $\mathrm{PIE}{ }^{*}$ bherh2- 'to cut'); PSl. * ${ }^{\prime} z r d$ - 'proud, arrogant', cf. Sn grd 'ugly', BCMS grd 'proud, arrogant', Ru gordyj 'proud', Cz hrdý 'proud, brave', and Li gurdùs 'slow', La gurds 'tired' (<PIE ${ }^{\star}$ gwerH- 'heavy') (Snoj 2020: s.vv).

Alternatively to the variant in $-z d$-, explained as a result of dissimilation and "expressive" motivation, the variant can have be built componentially with a suffix $-z d$ - originating in the $\varnothing$-grade of the PIE ${ }^{\star}$ sed- 'sit' root. This formation can be plausibly supposed for a number of Slavic words in which the meaning of 'sitting', 'affixed to', 'situated on/at' is intrinsic to their meaning, e.g., PSl. gnězdo 'nest' ("that which sits on a branch"), ${ }^{\star}$ grozdr/s 'grape, cluster' ("that which grows, sitting on a branch"), a proposal for the PIE stage that goes back to Bloomfield 1927 (for further details see also Snoj 1992). The addition of $-z d$ - as '(while) sitting' remained a viable word formation through the Proto-Slavic stage, as evidenced by Lithuanian joti 'ride' and OCS jazditi 'ride' (Brugmann 1903-1904: 103; see also Greenberg and Dickey 2006). As we shall see below, the addition of the 'sit' meaning helps to explain the semantic shift.

Generally speaking, the innovation reflects the continued productivity of Slavic in the extension of word-formational patterns established in PIE and, in particular, may belong to the class of compounds that show vrddhi-grade lengthening as noted by Loma (2003: 272). In this regard it is worth noting the variation of the reflexes between the three potential Slavic accentual paradigms: Standard Slovene attests both gizda and gizda; the Slovene Prekmurje (Beltinci) dialect (non-tonemic) shows length in gizda but short root stress in adjective gïzdav (Novak 1996: s.vv.); Vasojevići dialect (Montenegrin Štokavian) gízda, gen. sg. gizdê (Stijović 1990: s.v.), which supports the interpretation of the Slovene gizda form as a (non-Hirt's Law) retraction to a long pretonic from a final short-stressed $a$; while Čakavian 
shows variation between short and long root stress in the verb: gizdāt and gïzdàt (Brač, Vukovič 2001: s.v.) and short (falling) stress in the adjective gizdav (Vis, Roki-Fortunato 1997: s.v.). The variation points to an ambiguity whether the root is lengthened by a laryngeal or morphological (vrddhi) lengthening. The variation noted for similar word shapes, such as ${ }^{\star}$ strěxa 'roof' (Štokavian strëha, Russian strexá); see discussion in Kapović 2015: 180-181.

\section{Semantic shift}

The South Slavic semantic development would seem to be a classic instantiation of melioration, that is, polysemy motivated by shifts in the application of the given word (Ullmann 1971: 119). The basic shift in application has been identified by Snoj: "Različnost pomenov govori za prvotno ${ }^{\star} g \hat{y} z d \sigma$ 'blato, ${ }^{\star}$ gyzdïti (se), ${ }^{\star}$ gyzdäti (sę) 'mazati (se) z blatom', kar se je v delu slovan. jezikov razvilo v 'packati, kvariti', v delu pa v "ličiti se"' (Snoj 2020, s.v. gizda), in effect, the application of something smearable in both a negative and a positive context. As similar kind of bifurcation occurred, for example, with e.g., Proto-Slavic *užasz 'amazement, horror' developing in the adjective to Czech and Slovak úžasný 'awesome, splendid', cf. BCMS užasan 'horrible', Russian užasnyj 'horrible', not unlike the shift in English for terrific 'wonderful', which still reflects its obvious formal connection to the related term terrify 'to frighten'.

The general thrust of this line of reasoning has been discussed by Jakubowicz:

Considering the semantics of the whole of the South Slavic vocabulary one may claim that in these languages the word initially referred to apparent elegance which was negatively evaluated by the intuentes, perhaps also to self-importance (cf. early Slovene gizda 'pride, conceit, aloofness'). With the course of time these lexemes lost their negative overtones (2017: 132)

At least a couple of details can be added to make sense of how the shift in application might have come about, which does not exclude Jakubowicz explanation, but enriches it. For one thing, if the root 
referring to 'mud' or 'excrement' still held association with the original meaning, then it would require either an ironic or exaggerated usage (e.g., 'this applesauce tastes like crap') or the further reinterpretation of words had become decoupled from its original meaning. An intermediate development, still polysemous, can be seen in the shift in the English word 'shit', which by the early twentieth century in the US could mean ' $[\mathrm{u}]$ nspecified objects, materials, activities, events, etc., of any sort; stuff, things; [sometimes] spec. (with possessive adjective) personal belongings' (OED, s.v, shit). In the Slavic case, the relevant time frame for the shift took place before the written period, so, unlike with the exemplification for English (for example, documented in the $O E D$ ), we are generally resigned to accept that the contextual circumstances are shrouded in the mists of time.

To bridge this gap, however, we can build a model of how such changes could have occurred based on observable data. For the sensedevelopment of ${ }^{*} g y z d$ - in its positive meanings, one might consider the following. In Upper Carniola (Slovenia), one can hear the Slovene phrase Glej, imaš broško! 'Look, you've got a brooch!', which refers not to sporting jewelry, but, rather, 'You've spilled something on your shirt. With the opposite evaluation, in American English one might hear "You've got some shit on your tie/shirt!", which of course never means that one has literal excrement on one's clothing, but that there is spilled food or a condiment on it. What has taken place in each of these examples, while seemingly opposite in terms of evaluation, is a substitution of one thing for another, a positively-marked item (brooch) for a negative one (food where it is unwanted, a stain); the other a negatively-marked item (shit) for a less-negatively-marked one (food, stain). The difference lies in the pragmatic intention of the speakers, where in the first case the speaker opts to preserve the face of the addressee, i.e., uses the term as a euphemism; the second seeks to achieve a degree of humiliation, albeit intended humorously. For that matter, contemporary American English abounds in positive readings of the word shit, any of which could serve as a model for the substitution of the kind needed to shift $g y z d$ - from 'crap' to 'gilding', e.g., "This is some good shit" means 'This is something of high quality'; "You've 
really got your shit together" means 'You're well-disciplined / You are thinking in an organized manner'; "This is the shit!" 'This is the best thing ever!' (in millennial-generation speech).

As was observed in the discussion of the formal aspects of the construction of the ${ }^{*} g y z d$ - root, the $-z d$ - can be motivated by a morpheme that was not merely "expressive," but that also carries the meaning of 'to be sitting' or, more abstractly, as in other cases with word-formational $-z d$-, 'perched upon', 'hanging from', 'situated on or about. This brings together the semantic development (for that matter, regardless of the melioration-pejoration cline) and the formal identification of the $-z d$ - morpheme originating in the PIE 'site' root.

Once the new evaluation of the term was available, that is, once a "thing" $g y z d-\varpi /-a$ was identifiable as something either neutral or positive, let us say, an item of adornment, perhaps an actual brooch, it is easy to see how the meaning of related forms can be extended; thus, to the adjective gyzdav- $\boldsymbol{b} /-a$ 'characterized by adornment' or the verb gyzdati 'to swagger in the manner of someone proud to show off one's adornment' or to be a person-oriented noun characterizing their personality focusing on their desire to show off adornment, a sign of opulence, a gyzdalinz.

\section{Conclusion}

In the foregoing text we have examined the process of melioration in the South Slavic instantiations and derivatives from the ProtoSlavic root ${ }^{*} g y z d$-, adding to the existing literature on the etymology of the word within Slavic two key insights. First, the form ${ }^{*} g y z d$ - is a compound of ${ }^{*} g y$ - 'something disgusting' $+{ }^{*}-z d$ - 'sitting, situated. Second, that a signifier for sitting matter (mud, stagnant water, excrement) can undergo a semantic flip through reinterpretation of its frame of reference. To support this view, parallel developments in English are adduced. The formal and semantic developments are mutually reinforcing, which increases the plausibility of the revised reconstruction. Furthermore, an archaic valuation of the meaning has been identified in a Bulgarian verb and the reasons for its retention have been elucidated. 


\section{KNJIŽEVNI JEZIK 31, 2020. [9-23]}

\section{Abbreviations}

BCMS = Bosnian, Croatian, Montenegrin, Serbian; $\mathrm{Cr}=$ Croatian; $\mathrm{Cz}$ = Czech $; \mathrm{La}=$ Latvian; $\mathrm{Li}=$ Lithuanian $; \mathrm{O}=$ Old; PIE = Proto-IndoEuropean; $\mathrm{PSl}=$ Proto-Slavic; $\mathrm{Po}=$ Polish $; \mathrm{Ru}=$ Russian, $\mathrm{Sk}=$ Slovak; $\mathrm{Sn}=$ Slovene

\section{References}

Bezlaj, France (1977): Etimološki slovar slovenskega jezika, Prva knjiga, A-J, Slovenska akademija znanosti in umetnosti - Institut za slovenski jezik - Mladinska knjiga, Ljubljana.

Bloomfield, Maurice (1927): "Indo-European ozdos, Greek ö $\zeta o \varsigma$, Germanic asts, etc." Language 3/4, 213-214.

Brugmann, Karl (1903-1904): "Beiträge zur germanischen un slavischen Wortforschung", Indogermanische Forschung 15, 87-104.

Dickey, Stephen M. (2001): "'Semelfactive' -nQ- and the Western Aspect Gestalt", Journal of Slavic Linguistics 9 (1), 25-48.

Derksen, Rick (2008): Etymological Dictionary of the Slavic Inherited lexicon, Brill, Leiden.

ESSČ = Elektronický slovník staré češtiny [online] (2006) Ústav pro jazyk český AV ČR, v. v. i., oddělení vývoje jazyka, Prague. http://vokabular.ujc.cas.cz (accessed 14 July 2020).

ESSja = Trubačev, O. N. (1980): Ėtimologičeskij slovar' slavjanskix jazykov. Praslavjanskij leksičeskij fond, vyp. 7 ( ${ }^{\star}$ golvačb - ${ }^{*}$ gyžati), Nauka, Moscow.

Gerov, Najdan (1895): Rečnik na bъlgarskija ezik 1: A - D, Sъglasie, Plovdiv.

Gluhak, Alemko (1993): Hrvatski etimološki rječnik, Cesarec, Zagreb.

Greenberg, Marc L.; Dickey, Stephen M. (2006): “Slavic *jazditi 'to ride’ and its Implications for the Development the Category of (In)determinacy", in: Jesenšek, Marko; Zorko, Zinka (eds) Jezikovna predanost. Akademiku prof. dr. Jožetu Toporišiču ob 80-letnici (= Zbirka Zora 44), Slavistično društvo - SAZU, Maribor - Ljubljana, 153-158. 
Hock, Heinz Henrich; Joseph, Brian D. (2009): Language History, Language Change, and Language Relationship: An Introduction to Historical and Comparative Linguistics (= Trends in linguistics. Studies and Monographs 218), Mouton de Gruyter, Berlin.

HSSJ = Majtán, Milan (ed.) (1991): Historický slovník slovenského jazyka 1: A-J, Jazykovedný ústav L'udovíta Štúra, Bratislava.

Jakubowicz, Mariola (2017): The Development of Words Across Centuries. An Outline of a Dictionary of Semantic Motivations Based on the Material of Slavic Adjectives Inherited from the Proto-Slavic Period, trans. Artur Zwolski (= Monographs 2), Institute of Slavic Studies, Polish Academy of Sciences, Warsaw.

Kapović, Mate (2015): Povijest hrvatske akcentuacije. Fonetika, Matica hrvatska, Zagreb.

Králik, Luubor (2015): Stručný etymologický slovník slovenčiny, Veda, vydavatel'stvo SAV, Jazykovedný ústav L’udovíta Štúra SAV, Bratislava.

Kurkina, Ljubov' V. (1992): Dialektnaja struktura praslavjanskogo jazyka po dannym južnoslavjanskoij leksiki / Narečna struktura praslovanskega jezika v luči južnoslovanske leksike, Slovenska akademija znanosti in umetnosti, Ljubljana.

Loma, Aleksandar (2003): "Zur frühslavischen Nominalkomposition und ihren indogermanischen Grundlagen", Studia Etymologica Brunensia 2, 267-277.

MSS = Bělič, Jaromír; Kamiš, Adolf; Kučera, Karel (1979): Malý staročeský slovník, Pedagogické nakladatelství, Prague.

Novak, Franc (1996): Slovar beltinskega prekmurskega govora (2nd ed., ed. Vilko Novak), Pomurska založba, Murska Sobota.

OED = Oxford English Dictionary (2020), University of Oxford Press, Oxford. https://www.oed.com.

Pokorny, Julius (1959): Indogermanisches Etymologisches Wörterbuch, Francke Verlag, Bern. https://www.win.tue.nl/ aeb/natlang/ie/ pokorny.html. 


\section{KNJIŽEVNI JEZIK 31, 2020. (9-23]}

$R B E=$ Rečnik na bălgarskija ezik (2nd ed.), (2006), t. 3 (G-Dejatel), AI "Prof. Marin Drinov", Sofia. https://ibl.bas.bg/rbe/.

RMJ = Koneski, Blaže (ed.) (1986): Rečnik na makedonskiot jazik so srpskohrvatski tolkuvanja, Makedonska kniga, Skopje.

RHSJ = Budmani, P.; Daničić, Đ. (1887): Rječnik hrvatskoga ili srpskoga jezika 3. dio, sv. 9 (davli-godoje), JAZU, Zagreb.

Ròki-Fortunãto, Ândro (1997): Lîbar vĩśkiga jazika, Libar Publishing, Toronto.

SEJP = Boryś, Wiesław (2010): Słownik etymologiczny języka polskiego, Wydawnictwo Literackie, Cracow.

Skok, Petar (1971): Etimologijski rječnik hrvatskoga ili srpskoga jezika, Jugoslavenska akademija znanosti i umjetnosti, Zagreb.

Skulina, Josef (1964): Severní pomezí moravskoslovenských nářečí, Československá akademie věd, Prague.

Slawski, Franciszek. (1974): Slownik praslowianski, t. 1, Zaklad narodowy im. Ossolinskich, Wrocław.

Snoj, Marko (1992): "K preučevanju starejših nominalnih kompozit: psl. *drozds in *strbnads", in: Miklošičev zbornik (= Obdobja 13), SAZU - Univerza v Ljubljani, Ljubljana, 193-200.

Snoj, Marko (2020): Slovenski etimološki slovar (3rd ed., online), ZRC SAZU, Ljubljana. http://www.fran.si.

Sokolov, O. M. (1978): "O meste semantiki v opisanii motivacionnoslovoobrazovatel'nyx otnošenij”, Voprosy slovoobrazovanija $v$ indoevropejskix jazykax, vyp. 2, Izd. Tomskogo universiteta, Tomsk, 3-16.

SSKJ = Slovar slovenskega knjižnega jezika (2nd ed., augmented, online), ZRC SAZU, Ljubljana. http://www.fran.si.

Stijović, Rada (1990): “Iz leksike Vasojevića”, Srpski dijalektološki zbornik 36, 119-380.

Ullman, Stephen (1957): The Principles of Semantics, Blackwell, Oxford. 
Vaillant, André (1974): Grammaire comparée des langues slaves, t. 4. La formation des noms, Editions Klincksieck, Paris.

Vuković, Siniša (2001): Rïčnīk sëlaškēga gövora. Rječnik dijalekta Selaca na otoku Braču, Laus, Split.

\section{Melioracija u južnoslavenskom. Slučaj slavenskog *gyzd-}

Sažetak: U članku se raspravlja o podrijetlu i razvoju praslavenske riječi ${ }^{\star} g y z d-\imath /-$ i njenim izvedenicama u pojedinim slavenskim jezicima, s posebnom obzirom na formalne i semantičke promjene koje prate njen razvitak od negativnog ('blato, izmet', 'nešto odvratno') u sjevernoslavenskim jezicima (zapadnim i istočnim) do pozitivnog značenja ('ukras, uljepšavanje,' 'izlika, uglađenost') u južnoslavenskim.

Ključne riječi: etimologija, praslavenski jezik, tvorba riječi, semantička promjena

Author's statement on the absence of conflicts of interest and compliance with general codes of ethics: The author confirms that there is no actual or potential conflict of interest related to this text and that the text is written in accordance with the codes of ethics according to the recommendations of COPE (Committee of Publishing Ethics). 